\title{
Elemental Sulphur Content Of Onion Bulb (Allium cepa L.) as affected by Cow-Dung, Nitrogen, and Weed interference in the Sokoto Rima Fadama
}

\author{
${ }^{*}$ B.A. Gambo, ${ }^{2}$ A.U. Dikko and ${ }^{3}$ M.D. Magaji \\ ${ }^{1}$ Department of Crop Production, University of Maiduguri, Borno State, Nigeria \\ ${ }^{2}$ Department of Soil Science, Usmanu Danfodiyo University, Sokoto, Sokoto State, Nigeria \\ ${ }^{3}$ Department of Crop Science, Usmanu Danfodiyo University, Sokoto, Sokoto State, Nigeria \\ [* Correspondence: E-mail:_gamboabba2006@yahoo.com; 8: +234(0)8035372197]
}

\begin{abstract}
Two field trials were conducted during the 2005/2006 and 2006/2007 dry season under irrigation at the Usmanu Danfodiyo University Teaching and Research Fadama Farm at Kwalkwallawa, Sokoto (Latitude $13^{\circ} 1^{\prime} \mathrm{N}$ and Longitude $5^{\circ} 13^{\prime} \mathrm{E}, 350 \mathrm{~m}$ above sea level) to study the effect of cow-dung, nitrogen and weed interference on the elemental sulphur content of onion (Allium cepa L.). The treatments consisted of three levels of cow-dung $(0,15$ and $30 \mathrm{t} / \mathrm{ha})$, three levels of nitrogen $(0,50$ and $75 \mathrm{~kg} / \mathrm{ha}$ ) and three weeding regimes (weedy check, 4 and 6 weeks after transplanting) laid out in a randomized Complete Block Design (RCBD) with three replications. The elemental sulphur content $(\mathrm{mg} / \mathrm{g})$ of the onion bulb, was studied. The result showed significant $(\mathrm{P}<$ 0.05) effect of cow-dung, nitrogen and weed interference on the elemental sulphur content of onion. Highest level of sulphur content were obtained with $15 \mathrm{t} / \mathrm{ha}$ cow-dung, $75 \mathrm{~kg} / \mathrm{ha}$ nitrogen and $4 \mathrm{WAT}$ weeding regime. Based on the finding of this study, it could be concluded that for optimum onion production in the Sokoto Rima Fadama, a combination of $15 \mathrm{t} / \mathrm{ha}$ cow-dung, $75 \mathrm{~kg} / \mathrm{ha}$ nitrogen coupled with the 4 WAT weeding regime is the most suitable.
\end{abstract}

Keywords: Cow-dung, nitrogen, weed interference, onion, sulphur, sokoto, Rima Fadama.

\section{INTRODUCTION}

Onion (Allium cepa L.) is a member of the Alliaceae family and is one of the most important vegetables in the world whose utility is ranked second to tomatoes (Brice et al., 1997). Onion can be grown on a wide range of climatic conditions, but thrives best at mild climate without excessive rainfall or extremes of heat and cold (Purseglove, 1972). It requires a land with optimum soil $\mathrm{pH}$ of $6.0-7.0$ with good tilth and high moisture content (Rahim at al., 1992). It is a thermo-and-photosensitive crop (Mondal, 1985). Hence, the production of bulbs in onion is controlled by photoperiod, though temperature has marked influence. The daylength requirement for onion varies from 11 -16 hours.

Onion is consumed in different ways by different people and forms an essential part of the traditional daily diet. It is a major spice item, and ranks among the top 5 vegetables in Nigeria, (NIHORT, 1986). The bulb is used traditionally as a medicinal herb for the treatment of measles, pneumonia, cold and catarrh. Recent studies have confirmed that onion helps in fighting osteoporosis or bone loss (Biochemist, 2005). Onion production is a viable industry that employs plenty of labour and the bulbs are traded in large quantities within and between countries of the world (Currah and Proctor, 1990).

Despite the ranking of onion as the second most important vegetable in Nigeria, the present production levels do not meet the demand of the teaming populace. Limited changes in the traditional production practices may still be lagging behind the national demand (Denton and Ojeifo, 1990). Though the consumption of onion cuts across the country, its production is limited to the northern part of the country, where even in the north; production is restricted to Fadama areas, and grown mostly during the dry season under irrigation. Similarly, the production level at present is below the optimum realized for other countries. For example, while it is $45 \mathrm{t} / \mathrm{ha}^{-1}$ for the Republic of Niger, in Nigeria, it is just $15 \mathrm{t}^{\mathrm{h} \mathrm{ha}^{-1}}$ (FAO, 2005).

The consumers preference is for the higher pungent (high sulphur content) onion bulbs. The sulphur compound $\mathrm{n}$ - propyl disulphate in onion is more of a genetic trait, than environmental (Cobly, 1975). Denton and Ojeijo (1990) had earlier confirmed the consumer preference for the red onion variety due to its high pungency. Hence, this study was aimed at studying the effect of cow-dung, nitrogen and weed interference on the elemental 
sulphur content of onion, with a view to fashioning out the ideal combination for optimum, highly pungent onion production in the Sokoto Rima Fadama.

\section{MATERIALS AND METHODS}

Field trials were conducted during the $2005 / 2006$ and 2006/2007 dry seasons at the Fadama Teaching and Research Farm of the Usmanu Danfodiyo University, Sokoto. Sokoto lies on latitude $13^{0} 0 \mathrm{E}$ and longitude $5^{\circ} 15^{\prime} \mathrm{N}$ and about $350 \mathrm{~m}$ above sea level (Kowal and Knabe, 1972). Sokoto falls under the Sudan Savannah agro-ecological zone of Nigeria. The climate is characterized by a long dry season with cool dry air during the Harmattan, from November to February, and hot season from March to May then followed by a short rainy period from June to September (Davies, 1982). The experimental site is usually submerged by flood water from August to October. Average temperature ranges from 18.7 to $39^{\circ} \mathrm{C}$ during the coldest and hottest periods of the year respectively.

The treatments consisted of factorial combination of three levels of cow-dung $(0,15$ and $30 \mathrm{t} / \mathrm{ha})$, three levels of nitrogen $(0,50$ and $75 \mathrm{~kg} / \mathrm{ha}$ ) and three weeding regimes (weedy check, 4 and 6 WAT) laid out in a Randomized Complete Block Design with three replications. This gave a total of 81 plots each measuring 3 X $3 \mathrm{~m}$ with $1 \mathrm{~m}$ inter-row paths and watering channels. The total land area was $783 \mathrm{~m}^{2}$. Seeds of "Yar-ankara Ja" (Ex - Accra Red) were obtained from Institute for Agricultural Research, Ahmadu Bello University, Zaria. Nursery beds of $1.0 \times 3.0 \mathrm{~m}$ were marked out and cleared, then the seeds drilled into rows $15 \mathrm{~cm}$ apart. The research site being a Fadama land is marshy and flooded during the rainy season. This was allowed to recede considerably, then a tractor was used for mechanical ploughing and harrowing. The large clods were broken down in order to make the land into a fine tilt, after which 81 plots of $3 \times 3$ $\mathrm{m}$ each were measured, demarcated and laid out. Irrigation and drainage channels of $1 \mathrm{~m}$ were also made for conveyance and drainage of excess water.

Transplanting was done on $25^{\text {th }}$ December, when the seedlings were about $15 \mathrm{~cm}$ in height. A three-day irrigation interval was maintained for the first four weeks, then extended to a 7 days interval till 14 days to harvest, when irrigation was stopped completely so as to cure the bulbs. First weeding was done at 4 WAT, while the second was at 6 WAT. Cow-dung at 0,15 and 30 t/ha was applied at land preparation, while nitrogen at 0,50 and 75 $\mathrm{kg} / \mathrm{ha}$ was split applied at 4 and 6 WAT respectively as prescribed by treatment.

The parameter measured was elemental sulphur content $(\mathrm{mg} / \mathrm{g})$ of the onion bulbs. The Turbimetric digestion Methods of elemental $\mathrm{S}$ determination of plant tissue as outlined by AOAC, (1990) was used. The data collected were subjected to analysis of variance using the statistical analysis systems (SAS) package. Treatment means were compared for significant differences using the least significant difference using SAS software.

\section{RESULTS}

Table 1 shows the effect of cow-dung, nitrogen and weed interference on the elemental sulphur content $(\mathrm{mg} / \mathrm{g})$ of onion during the 2005/2006 and 2006/2007 dry seasons and the combined analysis at Sokoto, while Table 2 shows the various interactions.

The sulphur content $(\mathrm{mg} / \mathrm{g})$ of onion was significantly $(\mathrm{P}<0.05)$ affected by cow-dung, nitrogen and weed interference in both seasons and the combined. The sulphur content for the varying levels of cow-dung applied were statistically different, though the values for 15 and $30 \mathrm{t} / \mathrm{ha}$ were statistically at par. Nitrogen also had a significant $(\mathrm{P}<0.05)$ effect on the sulphur content of onion in both seasons and combined analysis.

The values for the control and the $50 \mathrm{~kg} / \mathrm{ha}$ nitrogen were statistically similar but not for 2007. Weed interference affected the sulphur content of onion at all levels. Weeding at 4 and 6 WAT gave statistically similar values. Interaction of cow-dung and nitrogen, cowdung and weed interference was found to be significant $(\mathrm{P}<0.05)$ in 2005. Weed interference at 4 WAT was at par with 6 WAT in terms of their effects on onion sulphur content in 2007 season and combined analysis. At 4WAT, sulphur content value in 2007 and combined analysis were 0.116 and $0.110 \mathrm{mg} / \mathrm{g}$ respectively.

\section{DISCUSSION}


The sulphur compound $\mathrm{n}$ - prophyl disulphate content in onion is genetically determined. The pungency of the "Yar Ankara Ja" studied is perhaps more of genetic than an environmental trait. Increase in the dosage of nitrogen led to increase in the sulphur content. IAR (1985) earlier stated that varieties of onion differ in such characters as bolting, bulb size, maturity date, pungency, bulb shape, colour, firmness and dry matter content. IAR (1984) also stated of the two major cultivated varieties (white and red), the red variety has a high pungency.

The relatively less mean sulphur contents obtained from the weedy check tally with the earlier works of Hewson and Roberts (1973) and Akobundu (1989). Interaction of cow-dung and weed interference revealed that weeding at 4 WAT coupled with cow-dung at the 15 t/ha produced the highest sulphur content $(0.167 \mathrm{mg} / \mathrm{g})$ in 2007.
A combination of $75 \mathrm{kgN} / \mathrm{ha}$ and $15 \mathrm{t} / \mathrm{ha}$ cowdung gave the highest sulphur content values, hence high pungency. The least pungent onions were obtained from the weedy checks. The continued association of the crop with a multitude of weeds, may have weakened the onion from the uptake and further utilization of the scarce soil nutrients due to competition.

\section{CONCLUSION}

The application of cow-dung, nitrogen and weed interference had a significant effect on elemental sulphur content of onion grown under irrigation during the 2005/2006 and 2006/2007 dry seasons at the Sokoto Rima Fadama. Based on the finding of this study, a combination of 15 t/ha cow-dung, $75 \mathrm{~kg} / \mathrm{ha}$ nitrogen and $4 \mathrm{WAT}$ weeding regime is recommended for optimum highly pungent onion production in the Sokoto Rima

Table 1: Effect of cow-dung, nitrogen and weed interference on the sulphur content $(\mathrm{mg} / \mathrm{g})$ of onion during 2005/2006 and 2006/2007 dry seasons and the seasons combined in Sokoto.

\begin{tabular}{|c|c|c|c|}
\hline Treatment & 2006 & 2007 & Combined \\
\hline \multicolumn{4}{|l|}{ Cow dung (t/ha) } \\
\hline 0 & 0.084 & $0.099 \mathrm{~b}$ & $0.092 \mathrm{~b}$ \\
\hline 15 & 0.098 & $0.106 \mathrm{a}$ & $0.103 \mathrm{a}$ \\
\hline 30 & 0.099 & $0.108 \mathrm{a}$ & $0.103 \mathrm{a}$ \\
\hline $\mathbf{S E} \pm$ & 0.0019 & 0.0015 & 0.0020 \\
\hline Level of significance & $*$ & $*$ & $*$ \\
\hline \multicolumn{4}{|l|}{ Nitrogen (kg/ha) } \\
\hline 0 & $0.088 \mathrm{~b}$ & $0.098 \mathrm{~b}$ & $0.094 \mathrm{~b}$ \\
\hline 50 & $0.089 \mathrm{~b}$ & $0.111 \mathrm{a}$ & $0.096 \mathrm{~b}$ \\
\hline 75 & $0.104 \mathrm{a}$ & $0.104 a b$ & 0.107 \\
\hline $\mathbf{S E} \pm$ & 0.0019 & 0.0022 & 0.0019 \\
\hline Level of significance & $*$ & $*$ & $*$ \\
\hline \multicolumn{4}{|l|}{ Weeding (WAT) } \\
\hline 0 & 0.072 & $0.083 \mathrm{~b}$ & $0.077 \mathrm{~b}$ \\
\hline 4 & 0.106 & $0.116 \mathrm{a}$ & $0.110 \mathrm{a}$ \\
\hline 6 & 0.103 & $0.114 \mathrm{a}$ & $0.109 \mathrm{a}$ \\
\hline $\mathbf{S E} \pm$ & 0.0019 & 0.0015 & 0.0013 \\
\hline Level of significance & ns & $*$ & $*$ \\
\hline \multicolumn{4}{|l|}{ Interaction } \\
\hline $\mathbf{F} \times \mathbf{N}$ & * & * & ns \\
\hline $\mathbf{F} \times \mathbf{W}$ & ns & * & ns \\
\hline $\mathbf{N} \times \mathbf{W}$ & ns & ns & ns \\
\hline
\end{tabular}

Means followed by the same letter(s) within treatment group are not significantly different at 5\% probability level using LSD test. $\quad *$-Significance at $5 \%$ level $\quad \mathrm{ns}=$ Not significance at $5 \%$ level

Table 2: Interaction of Cow-dung and Nitrogen on Sulphur Content $(\mathrm{mg} / \mathrm{g})$ in 2005/2006 and 2006/2007 dry seasons at Sokoto 


\begin{tabular}{|c|c|c|c|}
\hline \multirow[t]{2}{*}{ Cow-dung (t/ha) } & \multicolumn{3}{|c|}{ Sulphur Content (mg/g) } \\
\hline & 0 kg N/ha & $50 \mathrm{~kg}$ N/ha & $75 \mathrm{~kg} \mathrm{~N} / \mathrm{ha}$ \\
\hline \multicolumn{4}{|l|}{2006} \\
\hline 0 & $0.105 b$ & $0.093 \mathrm{c}$ & $0.095 \mathrm{c}$ \\
\hline 15 & $0.110 \mathrm{~b}$ & $0.0833 \mathrm{a}$ & $0.104 \mathrm{~b}$ \\
\hline 30 & $0.096 \mathrm{c}$ & $0.089 \mathrm{~d}$ & $0.069 \mathrm{e}$ \\
\hline $\mathrm{SE} \pm$ & & 0.0034 & \\
\hline \multicolumn{4}{|l|}{2007} \\
\hline 0 & $0.097 \mathrm{a}$ & $0.102 \mathrm{~d}$ & $0.101 \mathrm{~d}$ \\
\hline 15 & $0.112 b$ & $0.120 \mathrm{a}$ & $0.110 \mathrm{c}$ \\
\hline 30 & $0.102 d$ & $0.112 b$ & $0.084 f$ \\
\hline $\mathrm{SE} \pm$ & & 0.0026 & \\
\hline
\end{tabular}

Within 2006 and 2007, means followed by the same letter(s) across rows and columns are not significantly different at $5 \%$ probability level using DMRT

\section{REFERENCES}

Akobundu, I.O. (1989). Weed Science in the Tropics, Principles and Practices. A Wiley Inter-science Publication. John Wiley and Sons, New York, $2^{\text {nd }}$ Edition, 5 pp22.

AOAC (1990): Association of Analytical Chemists. Official Methods of Analysis Manual. 15 (edition) Washington, D.C.

Biochemist (2005): http://www.biochemist.com Niwsitem 16325,22/4/2005.

Colby, E. (1975): Crops of the Drier Regions of the World. Oxford University Press, London. Pp. $71-74$.

Currah, L. and Proctor, F.J. (1990). Onions in Tropical Regions. Bulletin 35. National Resources Institute, Chartham, UK. Pp 232.

Davies, G. (1982). Rainfall and Temperature, Sokoto State Maps. An Atlas of Physical and Human Resources. John Wiley and Sons Inc. New York.

Denton, L. and Ojeifo, I.M. (1990). Onion Production Practices and their Improvement in Nigeria. Onion Newsletter for the Tropics. Vol. 2, pp $10-$ 13.

FAO (2005). Food and Agricultural Organisation of the United Nations. FAOSTAT data, 2005.

IAR (1984). Annual Reports. Institute of Agric. Research Samaru, ABU, Zaria.

IAR (1985) Annual Reports. Institute of Agric. Research Samaru, ABU, Zaria.

NIHORT (1986). National Institute of Research, Jericho, Ibadan Annual Reports.

Roberts, H.A. and Hewson, R.T. (1973). Some Effects of Weed Competition on the Growth of Onions. J. Hort. Sci. (48), Pp $51-57$. 